\title{
SURVEY OF POSTGRADUATE EDUCATION AVAILABLE TO WOMEN WORKING PART-TIME IN PSYGHIATRY*
}

\author{
By Dr Dorothy Black \\ Lecturer in Psychiatry, University of Sheffield
}

\section{Introduction}

In the past five years increasing concern has been expressed within the medical profession at the wastage of medical manpower arising from the failure fully to utilize the skills of women doctors who are only able, because of domestic commitments, to work part-time.

This concern is particularly relevant to psychiatry, which historically has always relied heavily on medical and clinical assistants to fill service posts. In consequence, perhaps there are more women working in non-training grade posts in psychiatry than in other medical specialties. A recent survey (Savage and Wilson, 1977) confirms, however, that women see themselves especially suited to the practice of psychiatry.

The Royal College of Psychiatrists since its inception has accepted the principle of equivalent part-time training qualifying a candidate to attempt the M.R.C.Psych. Previous surveys have shown that women in psychiatry are well motivated to achieve higher qualifications (Black, 1974; Ashurst, 1975). Brook (1976) in a survey of recently appointed consultants draws the inference that the majority of women consultants have spent their training period in areas with less adequate postgraduate education facilities; nevertheless over one-third of his women respondents had achieved a consultancy following part-time training.

As part of the inquiry by the Working Party on Women in Psychiatry inaugurated in February 1976, I undertook to survey the postgraduate education available to women working part-time, and incidentally to make some assessment of the frequency and use of H.M.(69)6 posts. This grade was recommended by the DHSS to increase the number of part-time training posts available to women. Recent comment in a leading article of the British Medical Foumal has noted the wide variation between regions in its implementation.

\section{Method}

In March and early May 1976 a letter was sent to all Clinical Tutors inquiring about the availability of educational facilities for women working part-time in psychiatry, both in training grade posts and in non-training grades, i.e. Medical and Clinical Assistants. In all, 238 letters were sent out, and there were just over 100 replies. The response rate from all the Divisions was approximately 40 per cent, with the exception of Scotland and Northern Ireland with a 70-80 per cent response rate, and an exceedingly low response rate from Eire. It should be noted, however, that in some Divisions the Chairman of Division replied on behalf of several colleagues.

A more detailed breakdown of the situation in the Divisions follows.

\section{Scotland}

The overall availability of both training and attendance at D.P.M. and M.R.C.Psych. courses setmed very good.

However, there were some anomalies: in the Lothian Region non-training grades would have to pay their own fees if attending the Edinburgh M.R.C.Psych. course; though, if possible, their posts would be varied to part-time training grades, when their fees would be paid by the Health Board.

In Glasgow minimal session holders would have to use their own time to attend higher degree courses, though they might be allowed some study time within sessional hours. Similarly in Glasgow, precedence to attend the Day Release course is given to training grade applicants.

Adverse comments raised in replies were the sparsity of applicants in some Areas, and the difficulty in pairing a post, which in one Area they had found was a more acceptable way of obtaining extra finance. In Stirlingshire they had been unable to obtain finance to fund part-time training posts.

\section{Northern Ireland}

The situation seemed very satisfactory-there were large numbers of women in part-time training posts and good educational facilities available to all, whether training or non-training grades. These facilities were funded by the Special Mental Health Scheme, organized by the Postgraduate Medical Education Board. In consequence, perhaps, there was an increasing number of women moving into psychiatry.

* This survey was carried out in connection with the drafting of the Working Party's memorandum on 'Women in Psychiatry', published in the last issue of the Bulletin. 
Eire

The structure of the Health Service here appears to differ from that of the United Kingdom, in that there are no part-time posts, whether in training or non-training grades. One comment made was 'I would see no place for part-time junior doctors unless they were supernumerary to our permanent establishment. ... I do not believe that anyone working in a part-time capacity as a general consultant in psychiatry can do the job properly.'

Training is organized by the Postgraduate Psychiatric Training Board in Dublin.

\section{Wales}

Some replies indicated that time spent at educational courses would be on a pro-rata basis, dependent on the number of sessions worked (in non-training grades), though the doctors would be encouraged to attend.

\section{North East Division:}

\section{Durham and Northumberland}

All local and regional educational facilities were available to non-training part-time posts. The M.R.C.Psych. course is run in Newcastle, and this might involve considerable travelling time for a part-timer. No part-time training grade posts were reported.

\section{Torkshire}

Non-training grade posts can only attend the Leeds M.R.C.Psych. course by special arrangement. In one District they could attend local courses, but were not eligible for the M.R.C.Psych. course.

\section{Northern Division:}

There were a few part-time training posts available; but all part-timers of all grades were eligible to attend both local facilities and the Manchester M.R.C.Psych. course.

It was felt that the health authorities were still not committed to the concept of part-time consultant posts, but this would be inevitable.

\section{Midlands Division:}

All grades had access to either the Sheffield, Birmingham, or Nottingham M.R.C.Psych. courses, as well as all local educational facilities.

The Birmingham-Midland Scheme for training married women doctors provided supernumerary training posts.
In the Trent Region, part-time training grades were available, but there had been experience of long delays in the creation and funding of $69 / 6$ posts.

\section{Southern Division:}

Non-training grades had access to all training facilities; but in one Area there was no access to an M.R.C.Psych. course. There seemed to be a dearth of part-time training posts, and comment was made about the difficulty of funding these. It was felt the AHA was resistant to approving part-time posts, or allowing suitable part-time women to move into higher training grades.

\section{Chiltern and Thames Valley Division:}

Good educational facilities were available to all part-time grades. Apart, however, from the Oxford Married Women's Scheme which provided supernumerary posts up to four sessions per week, there were no part-time training posts reported. It was felt that some areas would only be prepared to offer part-time training posts by splitting one full-time post; this would necessitate there being two parttimers prepared to share the post.

A comment was made about the disadvantage of not being able to advertise for supernumerary parttime training posts.

One interesting experiment was reported from Friern Hospital of a re-entry introductory course for married women moving into psychiatry.

\section{East Anglian Division:}

Non-training grades could attend educational courses on a pro-rata basis only.

\section{South West Division:}

All grades had equal access to both local facilities and the Bristol M.R.C.Psych. course. Some parttime training posts were reported.

\section{Summary}

Overall there seem to be adequate educational facilities, both within hospitals and with access to major centre M.R.G.Psych. courses. In some parts of England, access to M.R.C.Psych. courses was limited because of the travelling time involved. This would be a particular disadvantage to a part-time doctor as it might well encroach unacceptably on her 'free' time, particularly those in the non-training grades, working on a sessional basis.

Other disadvantages experienced by the nontraining grade post-holders were:

(I) They might have to pay for M.R.C.Psych. courses. 
(2) Training grade posts had preferential access to M.R.C.Psych. courses.

(3) Study time was given on a pro-rata basis, which might mean that additional time was spent outside 'working' hours in travelling and attendance on courses.

(4) The Department, e.g. a University Department running the course might exclude nontraining grade applicants.

(5) Many of the non-training grade posts, particularly that of Clinical Assistant, had limited clinical experience, in that their working time was spent in circumscribed areas of clinical work. This inevitably hindered their appreciation of any educational course available to them.

The increasing number of Registrar rotating schemes sometimes makes it difficult to allow a parttime training post to be integrated, as the holder may need to stay twice as long in any module to gain adequate experience. It might be recommended that recognized training posts for part-timers should be maintained outside the rotation in all Areas, but allowing equal access to all modules.

Some of the anomalies raised could be dealt with by taking part-time training posts out of the hands of Regional and Area Authorities, to be funded centrally.

The 'pairing' of training posts-seen as a cheap economic solution-will prevent the single applicant from obtaining a post, and thus bar her from access to further training.

The principle of access to educational facilities being available to all grades-whether training or non-training must be accepted. The Clinical Assistant grade is particularly disadvantaged in that the holder not only may have to pay for further training but must often use her 'free' time for attendance at courses. The latter she may choose to do, but the financial disincentive should be removed, either by waiving fees, or providing one or two paid sessions for attendance at courses (a precedent already exists in Section 63 payments to general practitioners attending educational courses).

With few exceptions there seemed among the respondents much enthusiasm and determination to enable the part-time woman to have as full and adequate training and educational opportunity as her full-time peer. Many comments suggested that the anomalies and inadequacies lay more often at administrative level, where procrastination occurred, partly because of funding problems. There did, however, seem to be evidence in some Areas of resistance to the whole concept of the part-time woman doctor, and more particularly to her achieving further seniority if her qualifications increased.

It would seem that it is at this administrative level that the College needs to press for improvement to ensure a continuing entry of women into psychiatry, and to allow full utilization of their increasing skills within the specialty thereafter.

\section{References}

Savage, R. \& Wirson, A. (1977) Foumal of the Royal College of General Practitioners, 27, 363.

Brack, D. (1974) News and Notes. British Fournal of Psychiatry. October: $\mathrm{p}$ 10.

Ashurst, P. (1975) News and Notes. British Journal of Psychiatry. April: p 9.

Broox, C. P. (1976) Report to the Working Party on Women in Psychiatry.

HM(69)6. Department of Health and Social Security, I969.

Need Part-Time be Second Rate? British Medical Joumal (1977), ii, 210

\section{PAPERS FOR THE ANNUAL MEETING, $197^{8}$}

The Programmes and Meetings Committee invites members of the College to submit papers on miscellaneous topics for presentation at the Annual Meeting, which is to be held on 4,5 and 6 July 1978. Depending on the number offered, the Committee is prepared to make arrangements for parallel sessions to enable as many papers as possible to be read. I would be grateful to hear from members who have papers which they would like to present. The closing date for the receipt of summaries is 28 February 1978 .

E. G. LuGAs

Honorary Secretary

Programmes and Meetings Committee 